\title{
KEPOLISIAN DALAM MENANGGULANGI TINDAK PIDANA KEKERASAN DALAM RUMAH TANGGA DI WILAYAH HUKUM POLSEK MANDAI POLRES MAROS
}

\author{
The Police in Managing Criminal Violence in Household in the Mandai POLSEK jurisdiction \\ of Maros Regency Police Resort \\ Marlisa Ruhunlela ${ }^{1}$, Marwan Mas $^{2}$, Yulia A. Hasan ${ }^{2}$ \\ ${ }^{1}$ Mahasiswa Program Studi Ilmu Hukum Program Pascasarjana Universitas Bosowa \\ ${ }^{2}$ Prodi Ilmu Hukum Universitas Bosowa \\ Email: marlisa.ruhunlela@gmail.com
}

Diterima: 08 Agustus 2019/Disetujui: 09 Desember 2019

\begin{abstract}
ABSTRAK
Tujuan penelitian ini adalahuntuk mengetahui dan menganalisis upaya kepolisian dalam menanggulangi tindak pidana Kekerasan Dalam RumahTangga di wilayahhukumPolsekMandai dan. untuk mengetahui dan menganalisis Hambatanhambatan yang dihadapi penyidik kepolisian dalam upaya menanggulangi tindak pidana Kekerasan Dalam RumahTangga di wilayah hokum Polsek Mandai. Penelitian yang digunakan adalah penelitian hukum empiris yaitu suatu metode penelitian hukum yang berfungsi untuk melihat hukum dalam artian nyata dan meneliti bagaimana bekerjanya hukum di lingkungan masyarakat. Penelitian dilakukan di wilayah hukum Polsek Mandai Polres Maros, dan yang menjadi fokus pada peneilitian ini ada dua yakni: Preventif dan Represif: Hasil penelitian menujukkan bahwa upaya penanggulangan dilakukan secara preventif dan represif. Sementara kendala yang dihadapi dalam perlindungan perempuan korban kekerasan dalam rumah tangga adalah tidak adanya peraturan pelaksana terkait perintah perlindungan, keterbatasan dana dan keluarnya hasil visum et repertum membutuhkan waktu yang lama, keterbatasan sumber daya manusia seperti tidak adanya tenaga psikolog, kurang maksimalnya pelayanan konseling untuk korban, dan kurangnya pemahaman polisi terhadap pentingnya perintah perlindungan bagikorban. Keempat, keterbatasan sarana prasarana dan terdapat korban yangenggan ditempatkan di rumah aman.
\end{abstract}

Kata Kunci: Fungsi Polisi, Tindakan Kriminal, Kekerasan Dalam Rumah Tangga

\section{ABSTRACT}

The purpose of this study is; (1) To find out and analyze the efforts of the police in tackling the crime of violence in the household in the area of the Police Police in Mandai. (2) To find out and analyze the Obstacles faced by police investigators in the effort to overcome the crime of violence in the household in the area of Mandai Police. The research used is empirical legal research, which is a legal research method that functions to see the law in the real sense and examine how law works in the community. The study was conducted in the jurisdiction of the Mandai Police Station Maros Police, and the focus of the study was twofold: Preventive and Repressive: the results of the study showed that prevention efforts were carried out preventively and repressively. While the obstacles faced in protecting women victims of domestic violence are the absence of implementing regulations related to protection orders, limited funds and the release of visum et repertum results require a long time, limited human resources such as the absence of psychologists, lack of maximum counseling services for victims and the lack of understanding of the police regarding the importance of the order to protect victims. Fourth, limited infrastructure and there are victims who are reluctant to be placed in safe houses.

Keywords: police function, criminal acts, domestic violence

\section{PENDAHULUAN}

Indonesia merupakan negara hukum, hal ini ditegas kan dalam pasal 1 ayat (3) Undang-Undang Republik Indonesia Tahun 1945 Amandemen ketiga. Sehingga seluruh warga Indonesia maupun warga negara asing wajib mengikuti peraturan yang berlaku dan semua tin-dakantindakan yang berkaitan dengan kejahatan harus ditangani oleh lembaga pemerintah dengan sebagaimana mestinya sesuai dengan undang-undang (Barda, 2007; Didik, 2007). Hukum merupakan suatu norma yang ber-fungsi mengatur mengenai segala sesuatu tentang tingkah laku sehari-hari manusia dalam masyarakat agar tidak me-rugikan orang lain dan kepentingan umum. Hu-kum pada umumnya yang dimaksud adalah keseluruhan kum-pulan peraturanperaturan atau kaedah-kaedah dalam suatu kehi-dupan bersama: keseluruhan peraturan tentang tingkah laku yang 
berlaku dalam suatu kehidupan bersama, yang dapat dipaksakan pelaksanaannya dengan sanksi.

Polri merupakan lembaga eksekutif yang bergerak di garda terdepan dalam menangani kasus, maka dari itu semua tindakan yang diambil oleh polri harus sesuai dengan Undang-Undang, dan melihat kepentingan dari kedua belah pihak baik korban maupun pelaku. Dalam rangka pelaksanaan peran dan fungsi kepolisian, wilayah negara Republik Indonesia dibagi dalam daerah hukum menurut kepentingan pelaksanaan tugas Kepolisian Ne-gara Republik Indonesia (Rika, 2015;Ratna, 2016).

Daerah Maros memiliki ruang lingkup hukum. Ru-ang lingkup tersebut yang bertanggung jawab adalah Polda Daerah Sulawesi Selatan, selanjutnya di tingkat kabupaten yang bertanggung jawab adalah Polres, se-dangkan di tingkat kecamatan yang bertanggungjawab adalah Polsek. Polsek Mandai merupakan bagian dari instansi Kepolisian Republik Indonesia yang membawahi wilayah hukum Kecamatan. Polsek Mandai mempunyai tugas dan tujuan yang esensial yang sama. Kepolisian pada umumnya yakni untuk melayani, mengayomi dan melindungi masyarakat (Tubagus, 2001; Sulistyowati, 2006).

Sesuai dengan Undang-undang Republik Indonesia Nomor 2 Tahun 2002 tentang Kepolisian Negara Re-publik Indonesia Pasal 6 ayat 2 "Dalam rangka pelak-sanaan peran dan fungsi kepolisian, wilayah Negara Republik Indonesia dibagi dalam daerah hukum menurut kepentingan pelaksanaan tugas kepolisian Negara Re-publik Indonesia”.

Dalam pelaksanaan hukum dijalankan oleh aparat penegak hukum untuk menjalankan segala peraturan perundang-undangan. Untuk mengetahui lebih jelas mengenai tugas pokok kepolisian secara umum maka dapat dilihat dalam Pasal 13 Undang-undang Nomor 2 Tahun 2002 Tentang Kepolisian Negara Republik Indonesia yang menyatakan; Tugas Pokok Kepolisian Negara Re-publik Indonesia: (1) Memelihara keamanan dan keter-tiban masyarakat; (2) Menegakkan hukum; dan (3) Mem-berikan perlindungan, pengayoman, dan pelayanan ke-pada masyarakat

Fungsi Kepolisian adalah salah satu fungsi pemerintahan negara di bidang pemeliharaan keamanan dan ketertiban masyarakat, penegakan hukum, perlindungan, pengayoman dan pelayanan kepada masyarakat. Polisi menjalankan kontrol sosial dalam masyarakat, baik preventif (pencegahan) maupun represif (pemberantasan). Dalam peradilan, kepolisian mempunyai tugas untuk melakukan penyelidikan dan penyidikan.

Kekerasan dalam rumah tanggayang dulu dianggap mitos dan persoalan pribadi (private), kini menjadi fakta dan realita dalam kehidupan rumah tangga. Dengan berlakunya Undang-Undang No. 23 Tahun 2004 tentang Penghapusan Kekerasan Dalam Rumah Tangga yang disingkat (UU PKDRT)makapersoalan KDRT inimenjadi domain publik. Sebagian besar korban KDRT adalah kaum perempuan (istri) dan pelakunya adalah suami, walaupun ada juga korban justru sebaliknya, atau orang-orang yang tersubordinasi di dalam rumah tangga itu.

Kekerasan dalam rumah tangga merupakan masalah sosial serius yang kurang mendapat tanggapan dari masyarakat karena; pertama, KDRT memiliki ruang lingkup yang relative tertutup (pribadi) dan terjaga ketat pri-vasinya karena persoalan terjadi di dalam keluarga. Ke-dua, KDRT seringkali dianggap "wajar" karena diya-kini bahwa memperlakukan istri sekehendak merupakan hak suami sebagai pemimpin dan kepala rumah tangga. Ketiga, KDRT terjadi pada lembaga yang legal yaitu per-kawinan.

Adapun kasus yang berkembang di wilayah hokum polsek mandai dilihat dari salah satu berita terkait halnya kekerasan dalam rumah tangga yakni, Kasus perselingkuhan masih mendominasi kasus kekerasan dalam rumah tangga yang dilaporkan kalangan masyarakat ke Kepolisian.

Adapun tujuan yang ingin dicapai dalam penelitian ini adalah; (1) Untuk mengetahui dan menganalisis upaya kepolisian dalam menanggulangi tindak pidana Kekerasan Dalam Rumah Tangga di wilayah hokum Polsek Mandai. (2) Untuk mengetahui dan menganalisis Hambatan-hambatan yang dihadapi penyidik kepolisian dalam upaya menanggulangi tindak pidana Kekerasan Dalam Rumah Tangga di Wilayah hukum Polsek Mandai.

\section{METODE}

Penelitian yang digunakan adalah penelitian hukum empiris yaitu suatu metode penelitian hukum yang berfungsi untuk melihat hukum dalam artian nyata dan meneliti bagaimana bekerjanya hukum di lingkungan masyarakat. Penelitian dilakukan di wilayah hukum Polsek Mandai Polres Maros, dan yang menjadi fokus pada peneilitian ini ada dua yakni: Preventif dan Represif: Kemudian yang akan menjadi Populasi dalam penelitian ini adalah penyidik kepolisian polsek mandai dan masyarakat kecamatan mandai, dan yang menjadi sampel dalam penelitian ini adalah anggota kepolisian polsek mandai bagian Kriminal umum dan masyarakat kecamatan mandai.

Jenis dan sumber data yang digunakan adalah data primer dan data sekunder. Data primer adalah data atau informasi yang diperoleh secara langsung melalui penelitian lapangan dengan metode pengamatan dan wawancara atau interview, sedangkan data sekunder adalah data yang diperoleh dari bahan-bahan yaitu penelitian kepustakaan (Library Research). Pengumpulan data yang akan dilakukan adalah dengan cara penelitian kepustakaan (Library Research) dan obyek lapangan (Field Research).

Penganalisaan data dalam penelitian ini, dilakukan menggunakan pendekatan indukatif konstektual yaitu memulai dari informasi-informasi empirik yang diperoleh kemudian dibangun konsep-konsep kearah pengembangaan suatu teori substansi, teori yang bertolak dari data dan cerna dengan pengalaman lalu.

Pengabsahan data adalah untuk menjamin bahwa semua yang telah diamati dan diteliti peneliti sesuai (relevan) dengan data yang sesungguhnya ada dan memang benar-benar terjadi hal ini dilakukan peneliti untuk memelihara dan men-jamin bahwa data tersebut benar, baik bagi pembaca maupun subjek penelitian. Untuk memperoleh tingkat keabsahan data peneliti menggunakan triangulasi yaitu mengadakan per-bandingan antara sumber data yang satu dengan yang lain.

\section{HASIL DAN PEMBAHASAN}

1. Upaya Kepolisian dalam menanggulangi tindak pidana KDRT di Polsek Mandai

Perlindungan yang dilakukan Polsek Mandai terhadap korbanKDRT tidak serta merta hanya mengacu pada UU 
Penghapusan KDRT, tetapi padapelaksanaannya juga berdasarkan Perkapolri Nomor 3 Tahun 2008 tentang Pembentukan Ruang Pelayanan Khusus dan Tata Cara Pemeriksaan Saksi dan/atauKorban Tindak Pidana. Perlindungan terhadap perempuan korban KDRT oleh Polsek Mandai dilaksanakan melalui perlindungan secara preventif dan perilndungan secara represif.

\section{a. Perlindungan secara Preventif}

Perlindungan secara preventif adalah segala tindakan atau kegiatan yang dilakukan untuk mencegah semakin banyaknya korban yang diakibatkan oleh tindakKDRT. Perlindungan secara preventif dilakukan dalam bentuk kegiatan penyuluhandan sosialisasi sesuai dengan ketentuan Pasal 12 ayat (1) huruf a UU PKDRT yaitu: "pemerintah menyelenggarakan komunikasi, informasi, dan edukasi tentang kekerasan dalam rumah tangga."

\section{1) Kegiatan Penyuluhan kepada Masyarakat.}

Penyuluhan merupakan salah satu bentuk kegiatan preventif yang dilakukan oleh Polsek Mandai untuk mencegah terjadinya KDRT dengan memberikan pemahaman mengenai KDRT beserta akibat hukumnya kepada masyarakat Kabupaten Maros. Penyuluhan tersebut tidak dilaksanakan sendiri oleh Unit PPA melainkan dilaksanakan melalui kerjasama dan koordinasi dengan SatuanPembinaan Masyarakat (Sat Binmas) Polsek Mandai. Pada tahun 2017 telah diselenggarakan 2 (dua) kali penyuluhan mengenai pencegahan KDRT di 2 (dua) Kecamatan. Kegiatan penyuluhan ini bertujuan untuk memberikan penerangan dan pemahaman kepada masyarakatbahwa KDRT termasuk perbuatan pidana yang harus dihindari, menghimbau masyarakat untuk bisa melindungi diri sendiri, mengajak masyarakat untuk mencegah tindak KDRT dan melindungi korban KDRT serta memberikan informasi kepada masyarakat prosedur hukum penanganan kasus KDRT.

Hal ini dipertegas oleh hasil wawancara dengan informan penelitian sebagai berikut:

"kasus KDRT akhir-akhir ini semakin meningkat, untuk mengantisipasinya diadakan sosialisasi yang dimak-sudkan untuk memberikan pengetahuan kepada masyarakat tentang pencegahan diri dari tindak kekerasan KDRT" (Tanggal wawancara 21 Juli 2019)

Istilah kekerasan digunakan untuk menggambarkan perilaku, baik yang terbuka (overt), atau tertutup (covert), baik yang bersifat menyerang (offensive) atau bertahan (defensive), yang disertai oleh penggunaan kekuatan ke-pada orang lain. UU no. 23 tahun 2004, mendefinisikan ke-kerasan dalam rumah tangga adalah setiap perbuatan terhadap seseorang terutama perempuan, yang berakibat timbulnya kesengsaraan atau penderitaan secara fisik, seksual, psikologis, dan/atau penelantaran rumah tangga termasuk ancaman untuk melakukan perbuatan, pemaksaan, atau perampasan kemerdekaan secara melawan hukum dalam lingkup rumah tangga (Ps. 1:1).

Memang tidak ada definisi tunggal dan jelas yang berkaitan dengan kekerasan dalam rumah tangga. Meskipun demikian, biasanya kekerasan dalam rumah tangga secara mendasar, meliputi (a) kekerasan fisik, yaitu setiap per-buatan yang menyebabkan kematian, (b) kekerasan psiko-logis, yaitu setiap perbuatan dan ucapan yang mengaki-batkan ketakutan, kehilanagan rasa percaya diri, hilangnya kemampuan untuk bertindak dan rasa tidak berdaya pada perempuan, (c) kekerasan seksual, yaitu stiap perbuatan yang mencakup pelecehan seksual sampai kepada memaksa seseorang untuk melakukan hubungan seksual tanpa persetujuan korban atau disaat korban tidak menghendaki; dan atau melakukan hubungan seksual dengan cara-cara yang tidak wajar atau tidak disukai korban; dan atau menjauhkannya (mengisolasi) dari kebutuhan seksualnya, (d) kekerasan ekonomi, yaitu setiap perbuatan yang mem-batasi orang (perempuan) untuk bekerja di dalam atau di luar rumah yang menghasilkan uang dan atau barang; atau membiarkan korban bekerja untuk di eksploitasi; atau menelantarkan anggota keluarga.

Contoh kasus KDRT yang terjadi adalah Kasus KDRT yang melibatkan korban atas nama Rahmi Hamzah, dimana pelaku yang bernama Muksin dengan sengaja melakukan kekerasan dalam rumah tangga yang mengakibatkan luka biasa oleh korban. Kronologis kejadian, tersangka ditelpon oleh korban untuk pulang ke rumah, 5 menit setelah mendapat telpon tersangka telah berada di rumah dan marah kepada korban, terjadi pertengakaran antara tersangka dan korban. Karena emosi, tersangka kemudian mencekik leher korban dan mendorongnya hingga terjatuh ke lantai. Anak korban yang menjadi saksi kejadian membantu korban namun pada saat korban berdiri lagi, tersangka kembali mendorong korban dari belakang hingga akhirnya terjatuh dan tersangka mengambil botol kecap cap "Pala" dan memukulkannya kekepala korban, Selanjtnya pelaku mengambil botol yang berada ditangan korban dan memukulkannya lagi di kepala korban dan menarik baju daster korban hingga robek. Setelah itu, korban lalu menelpon saksi Nejo untuk memberitahukan kejadian dan saksi mengantarkan korban dengan dibonceng sepeda motor untuk melaporkan kejadian yang dialami ke Polsek Mandai. Atas perbuatannya tersangka melanggar pasal 44 ayat (1) subsd ayat (4) UU No. 23 Tahun 2004 tentang penghapusan kekerasan dalam rumah tangga lebih subsd. Pasal 351 ayat (1) KUHPidana.

Maka, dapat disimpulkan bahwa Perlindungan secara preventif dilakukan melalui kegiatan penyuluhan dan sosialisasi perlindungan perempuan dan anak Unit PPA bekerjasama denganFPK2PA. Kegiatan tersebut sesuai dengan ketentuan Pasal 12 ayat (1) hurufa UU PKDRT yaitu "pemerintah menyelenggarakan komunikasi, informasi,dan edukasi tentang kekerasan dalam rumah tangga.

\section{2) Sosialisasi Perlindungan Perempuan dan Anak Bekerja sama dengan Lembaga}

Kegiatan sosialisasi yang bersifat informatif dan edukatif ini dilaksanakanoleh Polsek Mandai dan beberapa lembaga forum penanganan korban kekerasan perempuan dan anak, Dinas Sosial, dan Kantor Pemberdayaan Masyarakat dan Perempuan. Polisi Polsek Mandai ikut serta dalam kegiatan sosialisasitersebut yang berperan sebagai pembicara karena kepolisian merupakan salah satulembaga yang bertugas memberikan perlindungan terhadap perempuan dan anak sertabertugas memberikan pemahaman terkait dengan prosedur hukum penanganan kasuskekerasan. Kegiatan sosialisasi yang telah dilaksanakan oleh polisi Unit PPA bekerjasama dengan FPK2PA pada tahun 2017 yaitu kegiatan sosialisasi perlindungan perempuan dan anak padaJanuari dan Juli 2017. Kegiatan sosialisasi tersebut bertujuan untuk memberikan edukasi kepada masyarakat mengenai fakta tentang kekerasan, menginformasikan ketentuan atau pera-turan tentang perlindungan perempuan dan anak, meng-himbau untuk tidak melakukan tindak kekerasan, mengajak masyarakat untuk ikut mencegah serta melindungi anak dan perempuan yang sering menjadi korban kekerasan (Khoidin dan Sadjiono, 2007; Masruchin, 2001). 
Hal ini didukung oleh hasil wawancara yang menyebutkan bahwa kegiatan sosialisasi yang bersifat informatif dan edukatif ini dilaksanakan oleh Polsek Mandai dan beberapa lembaga forum penanganan korban kekerasan perempuan dan anak, Dinas Sosial, dan Kantor Pember-dayaan Masyarakat dan Perempuan

Perempuan hampir selalu menjadi korban kekerasan karena budaya dan nilai-nilai masyarakat kita dibentuk oleh kekuatan patriarka, dimana laki-laki secara kultural telah dipersilahkan menjadi penentu kehidupan. Menurut Fou-cault laki-laki telah terbentuk menjadi pemilik 'kuasa' yang menentukan arah 'wacana pengetahuan' masyarakat. Kekerasan terhadap perempuan secara garis besar (pada umumnya) terjadi melalui konsep adanya control atas diri perempuan, baik terhadap pribadinya, kelembagaan, sim-bolik dan materi. Dengan demikian, ketika hubungan antar jenis kelamin dikonstruk melalui hubungan dominasi-sub-ordinasi, maka perempuan berposisi sebagai pihak yang diatur oleh laki-laki (Fathul, 2001;Parsudi, 2004). Bangu-nan relasi ini bekerja melalui seluruh system social tadi yang kemudian melahirkan identitas jender yang mem-bedakan laki-laki dan perempuan. Secara sosio-kultural, hubu-ngan laki-lakiperempuan (relasi jender) di Indonesia secara kompleks terbangun melalui beberapa alasan, antara lain: 1) laki-laki secara fisik lebih kuat dari pada perem-puan dan ada kemungkinan tingkat agresivitas yang tinggi memiliki dasar biologis pula. Dalam masyarakat laki-laki juga dibiasakan untuk melatih menggunakan fisiknya seka-ligus berkelahi, menggunakan senjata dan menggunakan intimidasi kekuatan sejak masa kanak-kanak, 2) dalam masyarakat ada tradisi panjang mengenai dominasi laki-laki terhadap perempuan, dan toleransi penggunaan kekuatan oleh laki-laki. Tradisi tersebut tertampilkan melalui film, pornografi, dan musik rok, serta media pada umumnya,

3) realitas ekonomi memaksa perempuan untuk menerima penganiayaan dari orang pada siapa dia bergantung, 4) pada tingkat individual, faktor psikologis berinteraksi dengan hal-hal yang disebutkan di atas, untuk menjelaskan bahwa sebagian laki-laki melakukan kekerasan dan sebagian perempuan menjadi korban kekerasan; sementara sebagian laki-laki lain tidak melakukan kekerasan tersaebut dan sebagian perempuan juga tidak menjadi sasaran kekerasan dan 5) pada akhirnya dapat disimpulkan bahwa ada per-bedaan kekuatan dan kekuasaan antara perempuan dan laki-laki dalam arti perbedaan yang dipersepsikan sebagai hak dan kemampuan untuk melakukan pengendalian terhadap satu sama lain (PKKNRI, 2007).

Maka ketika relasi kuasa tidak seimbang, kekerasan dan ketidakadilan menjadi suatu kemungkinan yang sangat besar muncul. Tetapi dalam kasus tertentu, bisa jadi ke-nyataan itu terbalik, dan laki-lakilah yang menjadi korban.

Secara biologis, jenis kelamin laki-laki dan perem-puan berbeda. Perempuan mempunyai rahim, mengalami menstruasi, hamil, melahirkan, dan lain sebagainya. Sifat nature perempuan ini mempunyai hubungan timbal balik dengan alam, karena sifatnya yang produktif dan kreatif.Perempuan merupakan produsen sistem kehidupan yang baru. Adapun, laki-laki identik dengan yang meng-eksploitasi alam. Kekuatannya diarahkan untuk menguasai dan menaklukkan alam sesuai dengan keinginan dan kepentingannya. Hal ini menyebabkan relasi kuasa dan eks-ploitasi antara laki-laki dan perempuan yang mengaki-batkan subordinasi perempuan. Masyarakat dan budaya mengkonstruksi perbedaan hubungan antara laki-laki dan perempuan tersebut untuk membedakan peran dan tugasnya. Berdasarkan struktur biologisnya, laki-laki diuntungkan dan mendominasi perempuan.

Perbedaan peran antara perempuan dan laki-laki disebabkan oleh adanya perbedaan biologis atau jenis kelamin. Teori nurture melihat perbedaan tersebut sebagai hasil konstruksi budaya dan masyarakat yang menempatkan laki-laki lebih unggul dari perempuan. Kelemahan struktur biologis perempuan menempatkannya pada posisi yang marginal dalam masyarakat. Perempuan dianggap tidak memiliki kekuatan fisik, lemah, emosional, sehingga hanya berhak mengerjakan pekerjaan yang halus, seperti pekerjaan rumah, mengasuh anak, dan lain-lain. Relasi sosial dilakukan atas dasar ukuran laki-laki. Perempuan tidak berhak melakukan hubungan tersebut. Dengan perbedaan semacam ini, perempuan selalu tertinggal dalam peran dan kontribusinya dalam hidup berkeluarga, bermasyarakat, berbangsa, dan bernegara. Konstruksi sosial menempatkan perempuan dan laki-laki dalam nilai sosial yang berbeda.

Konstruksi jender dalam masyarakat itu telah terbangun selama berabad-abad membentuk sebuah budaya yang diwariskan secara turun temurun dari satu generasi ke generasi berikutnya. Teori pembelajaran sosial (Social Learning Theory) menjelaskan bahwa kita belajar banyak tentang tingkah laku kita dalam konteks interaksi dengan orang lain. Teori ini beranggapan bahwa perilaku hubungan seks misalnya, dapat dipelajari tanpa meneliti ketika proses pembelajaran berlanrgsung, tetapi melalui observasi terhadap orang lain dan kejadian lain. Misalnya jika kita melihat seseorang dihukum karena melakukan hubungan seks pra nikah, kita harus menghilangkan kesukaan pribadi pada hubungan serupa itu. Untuk masalah penyerangan seksual secara luas, teori ini menggaris bawahi faktor-faktor yang betul-betul penting dari pengalaman masa lalu, seperti pengaruh pengasuhan, norma-norma social, kejadian biologis, dan bagaimana pengalaman seksual terakhir membentuk cara berpikir dan cara bertindak secara seksual.

Hasil penelitian tentang kekerasan terhadap istri dan kesehatan perempuan di Sulawsei Selatan memperlihatkan data tentang perempuan yang ayahnya pernah memukul ibu mereka, atau mertuanya talah memukul istrinya, lebih mungkin dianiaya oleh suaminya. Hasil serupa ditemukan dalam banyak studi internasional yang lain di Amerika serikat, Amerika Latin, dan Asia. Pada umumnya, para pene-liti percaya bahwa perempuan yang tak terlindungi terhadap kekerasan semasa kecilnya mungkin akan meli-hatnya sebagai suatu kejadian yang normal, dan karenanya tak pernah memperhatikan tanda-tanda peringatan dari suami penganiaya. Disisi lain, jika seorang anak laki-laki menyak-sikan ayahnya memukul ibunya, dia akan belajar bahwa hal itu adalah jalan terbaik untuk memperlakukan perempuan, dan karena itu dia lebih mungkin untuk kemudian meng-aniaya istrinya sendiri. Ini disebut sebagai "penularan keke-rasan antar generasi (intergenerational transmission of vio-lence)".

Proses inkulturasi dalam rumah tangga yang dilakukan melalui proses pengasuhan anak, menjadi cara belajar peran jender yang paling effektif tentang bagaimana menjadi lakilaki dan bagaimana menjadi perempuan yang diizinkan oleh masyarakat. Luce Irigaray, seorang feminis postmodernisme dari Perancis menandaskan bahwa "demokrasi dimulai dari rumah". Demokrasi yang menanamkan nilai-nilai hak asasi 
manusia, kesetaraan dan kebebasan, menurutnya, ditanam-kan pada awalnya dari rumah. Oleh sebab itu, ia yakin benar bahwa peranan ibu atau perempuan dalam mendidik anaknya di rumah menjadi sangat menetukan. Terutama pendidikan yang mengajarkan saling mengasihi, pengem-bangan aspek emosional, kesensitifan, keperdulian dan ke-terhubungan satu sama lain menjadi penting.

\section{b. Perlindungan secara Represif}

Perlindungan secara represif adalah segala upaya yang dilakukan Unit PPAPolsek Mandai dalam bentuk pelayanan terhadap korban KDRT untuk memberikan rasa aman dan menjamin keselamatan fisik dan psikis korban sebagai pelapor dan/atau saksi korban di wilayah hukum Polsek Mandai. Dalam rangka melaksanakan perlindungan kepada korban KDRT, Polsek Mandai juga menjalin kerjasama dengan Forum Penanganan Korban Kekerasan terhadap Perempuan dan Anak (FPK2PA), Dinas Sosial, dan Kantor Pemberdayaan Masyarakat dan Perempuan (KPMP) Kabupaten Maros. Prosedur penanganan kasus yang terdiri dari tindakan perlindungan dan penegakan hukum (penyelidikan dan penyidikan) di Unit PPAPolsek Mandai yakni: Pertama, dimulai dengan adanya laporan ataupun aduan (laporan polisi/LP) tindak KDRT yang terjadi di Wilayah Kabupaten Maros diterimaoleh polisi pelayanan masyarakat (yanmas) bagian Sentra Pelayanan Kepolisian Terpadu (SPKT). Di SPKT korban tidak hanya dapat melaporkan kronologi kejadianyang dialami, tetapi korban juga dapat berkonsultasi dengan polisi yanmas untukmenceritakan permasalahan rumah tangga yang dialaminya (konseling); Kedua, SPKT meneruskan laporan atau aduan tersebut ke Reskrim bagianUnit PPA guna dilakukan tindakan penyelidikan. Polisi pelayanan masya-rakat mengantarkan korban KDRT ke Unit PPA agar Unit PPA dapat segera memberikanpelayanan kepada korban KDRT. Perlindungan kepada korban diberikan bersamaan dengan dilakukannya tindakan penyidikan (penangkapan, penahanan, penggeledahan,penyitaan, pemanggilan dan pemeriksaan); Ketiga, dalam memberikan pelayanan ter-hadap korban, Unit PPA menjalin kerja sama dengan pihak rumah sakit untuk menangani korban yang memerlukan perawatan medis. Selain itu Unit PPA juga selalu berusaha memantau perkembangan kesehatan korban dengan men-jalin komunikasi dengan pihak rumah sakit serta mengajukan permohonan visumet repertum kepada pihak rumah sakit untuk digunakan sebagai salah satu alat bukti; Ke-empat, Polsek Mandai bekerja sama dengan Lembaga Swadaya Masyarakat (LSM) untuk memberikan pelayanan pendampingan psikologis atau konseling terhadap korban KDRT yangmengalami kekerasan psikis seperti trauma, tertekan atau ketakutan; Kelima, Unit PPA Polsek Mandai bekerja sama dengan lembaga jejaring penanganan korban kekerasan FPK2PA yang menyediakan rumah aman (shelter) dalam menanganikorban KDRT yang memerlukan tempat istirahat/tempat berlindung sementara untuk pera-watan lebih lanjut atau menjaga keselamatan dirinya; Keenam, guna penegakanhukum maka setelah proses penyi-dikan selesai dengan dibuatnya berkas perkara hasil penyidikan, polisi Polsek Mandai berkoordinasi dengan pihak Kejaksaan untuk pelimpahan perkara tersebut dan ketujuh, Unit PPA mengikuti/memonitoring pelaksanaan sidang pengadilan terhadap kasus KDRT yang telah diajukan melalui Penuntut Umum

Dalam rangka melaksanakan perlindungan kepada korban KDRT, Polsek Mandai menjalin kerjasama dengan
Forum Penanganan Korban Kekerasan terhadap Perempuan dan Anak (FPK2PA), Dinas Sosial, dan Kantor Pemberdayaan Masyarakat dan Perempuan (KPMP) Kabupaten Maros.

Disamping perlindungan yang dilakukan dengan melibatkan/kerja sama instansi lain sebagaimana telah diuraikan di atas, terdapat dua bentuk perlindungan lainnya yang dilakukan polisi selama kasus ditangani, yakni penyampaian perkembangan penanganan kasus kepada pelapor dan pemberian jaminan keselamatan korban yang mencabut aduannya.

Berdasarkan uraian di atas dapat disimpulkan bahwa bentuk perlindungan terhadap perempuan korban KDRT olehPolsek Mandai sesuai dengan Pasal 17 UU PKDRT dan Pasal 10 huruf c, d, f, i, j, k dan 1 Perkapolri Nomor 3 Tahun 2008. Pasal 17 UU KDRT menyatakan "Dalam memberikan perlindungan sementara, kepolisian dapat bekerjasama dengan tenaga kesehatan, pekerja sosial, relawan pendamping, dan/ataupembimbing rohani untuk mendampingi korban." Sedangkan perlindungan yang dilaksanakan sesuai dengan beberapa ketentuan dalam Pasal 10 Perkapolri Nomor 3 Tahun 2008 yaitu meliputi: a) Memantau kondisi kesehatan korban dan meminta visum et repertum; b) Melaksanakan pemberian konseling; c) Menempatkan korban di rumah aman; d) Memberitahukan perkembangan penanganan kasus kepada korban dan e) Menjamin keamanan korban yang mencabut aduannya.

Walaupun telah melaksanakan perlindungan sebagaimana ketentuan perundang-undangan, tetapi terdapat satu hal yang seharusnya menjadi hak korbanyang belum dilaksanakan oleh Polsek Mandai yakni memperoleh surat penetapan perintah perlindungan dari pengadilan sesuai ketentuan Pasal 16 ayat(3) UU Penghapusan KDRT. Menurut ketentuan Pasal 16 ayat (3) UU Penghapusan KDRT "Dalam waktu 1 x 24 (satu kali dua puluh empat) jam terhitung sejakpemberian perlindungan sebagaimana dimaksud pada ayat (1), kepolisian wajib meminta surat penetapan perintah perlindungan dari pengadilan." Sementara dengan adanya perintah perlindungan dapat menghindarkan korban dari intimidasi atau pengulangan tindak kekerasan yang dilakukan oleh pelaku karena apabila pelaku melanggar perintah perlin-dungan (misalnya mengintimidasi atau kembali melakukan KDRT) maka kepolisian dapat menangkap untuk selanjutnya melakukan penahanan tanpa surat perintah terhadap pelaku walaupun pelanggaran tersebut tidak dilakukandi tempat polisi itu bertugas. Kemudian penangkapan dan penahanan wajib diberikansurat perintah penangkapan dan penahanan setelah 1 x 24 jam. Penangguhan penahanan tidak berlaku terhadap penahanan tersebut. Perintah perlindungan yang belum pernah diajukan tersebut cukup penting mengingat dengan adanya jaminan perlindungan kemungkinan dapat mencegah terulangnya tindak KDRT terhadap korban.

Rumah, dipercaya oleh masyarakat sebagai tempat yang paling aman dan nyaman untuk ditempati. Rumah adalah tempat bermuaranya seluruh petualangan dan kelelahan. Di rumahlah orang bersikap paling natural, tidak dibuat-buat, tidak harus jaga image, dan sebagainya. Secara umum masyarakat beranggapan, bahwa tempat yang berbahaya adalah di luar rumah. Maka ketika rumah dituding sebagai tempat berlangsungnya kekerasan, semua orang mem-berikan respons yang beragam.

Karena KDRT terjadi dalam lingkup personal yang penuh muatan relasi emosi, penyelesaianya tidak segam-pang 
kasus-kasus kriminal dalam konteks publik. Suara perempuan atau korban kekerasan domestic cenderung membisu. Terdapat beberapa alasan yang menyebabkan tindakan KDRT seperti fenomena gunung es, lebih banyak kasus yang terpendam ketimbang yang terlihat.

Beberapa alasan yang membuat korban enggan melakukan tindakan hukum ketika terjadi kekerasan, antara lain: a. Bahwa tidakan kekerasan yang dialami adalah sesuatu yang lumrah terjadi, bahkan dianggap sebagai proses pendidikan yang dilakukan suami terhadap istri, atau orangtua terhadap anak. Anggapan ini dihubungkan dengan kepercayaan bahwa suami adalah pemimpin keluarga, sehingga mempunyai hak mengatur (kalau perlu dengan kekerasan) terhadap anggota keluarganya; b. Harapan bah-wa tindak kekerasan akan berhenti. Tindakan kekerasan mempunyai "siklus kekerasan" yang menipu. Hal itu di-bungkus sebagai rasa cinta dan komitmen pada pasangan-nya, tetapi terus berulang; c.Ketergantungan ekonomi. Jika perempuan memiliki kemandirian ekonomi dan mempunyai hak/wibawa dan kekuasaan di luar keluarga, tingkat keke-rasan oleh pasangannya menjadi lebih rendah; d. Demi anak-anak. Pengetahuan umum yang melihat anak akan menjadi korban konflik orangtua, seringkali menyebabkan perempuan mengalah. Sosok ideal perempuan menjelma pada diri seorang ibu yang berkorban serta membaktikan dirinya pada anakanak dan suami, sehingga kebutuhan dan identitas dirinya menjadi hilang dalam rutinitas rumah tangga yang dijalaninya. Pengorbanan ini tidak hanya hidup dalam budaya dan masyarakat, melainkan realitas agama. Bunda Maria digambarkan sebagai sosok ibu yang berkorban untuk anaknya dan mendapatkan kebahagiaan dalam membahagiakan orang lain. Para perempuan, menurut Daly, harus mampu mengatakan "tidak" terhadap moralitas pengorbanan, sehingga kedirian perempuan atau ethic of personhood (etika diri) menjadi muncul dalam menanggapi keinginan dan kebutuhan personal perempuan; e. Rasa lemah dan tidak percaya diri serta rendahnya dukungan dari keluarga dan teman. Pandangan masyarakat terhadap perempuan janda membuat perempuan korban kekerasan tetap mempertahankan perkawinannya, dan keluarga sulit memberikan dukungan sebagai akibat stigma tresebut; f. Tekanan lingkungan untuk tetap bertahan da-lam hubungan itu dan anggapan bahwa tindak kekerasan itu adalah akibat kesalahan dia.

Secara teoritis, para ahli studi perempuan menyebut alasan-alasan di atas dengan istilah Sindrom Tawanan (Hostage Syndrome) yaitu gambaran bagi perempuan yang terjerat secara fisik maupun psikologis oleh norma budaya dan masyarakat. Keterjeratan ini bisa terjadi dalam ke-luarga, seperti perempuan harus mengasuh anak dan suami, serta menganggap lumrah perlakuan kasar suaminya. Dalam masyarakat, perempuan tidak mempunyai hak untuk menentukan jodoh, sehingga kondisi psikologis perempuan mengalami sindrom ketergantungan dengan sistem nilai lakilaki. Pada awalnya, konsep sindrom tawanan ini dikembangkan untuk memahami keberhimpitan paradoksal dari tawanan (perempuan) pada penawannya (suami, masyarakat, dan budaya), dan kemudian diterapkan dalam upaya memahami situasi perempuan sebagai korban. Efek tawanan itu kemudian dikembangkan, baik oleh orang yang menawan atau oleh masyarakat pada umumnya. Sebagai tawanan masyarakat, perempuan korban sangat sulit untuk meninggalkan pasangannya, karena lingkungan sosial kema- syarakatan tidak memberikan dukungan yang cukup untuk melakukannya. Variabel dari realitas sosial kemasyarakatan itu antara lain norma perkawinan, peran perempuan dalam perkawinan, pesan yang diterima perempuan sejak masa kecil, tiadanya dukungan dalam keluarga dan masyarakat, tidak adanya sumber daya ekonomis yang memungkinkan bisa hidup mandiri, serta perlindungan hukum yang tidak memadai.

Dengan situasi sosial seperti itu, perempuan korban kemudian beralih ke sumber daya personalnya sendiri. Untuk dapat bertahan, ia merasionalisasi penganiayaan yang dialaminya sebagai respons alami yang ditampilkan pasangannya dalam menghadapi tekanan. Jadi, perempuan korban kemudian mengadopsi norma-norma budaya yang mengabsahkan kekerasan pasangan (laki-laki). Bahkan perempuan, pada akhirnya menginternalisasi pandangan bahwa perempuan bertanggungjawab untuk memastikan keber-hasilan perkawinan. Dalam kondisi atau keadaan keterjeratannya, perempuan akan dengan mudah menginternalisasi, menghayati banyak perasaan negatif, seperti rasa malu, bimbang, merasa berdosa, menyalahkan diri sendiri, dan sebagainya. Kondisi keterjebakan seperti ini dan ketidakmampuan mencari jalan alternatif pemecahan, menyebabkan perempuan sulit keluar dari kekerasan yang ada.

Penanggulangan awal harus dilakukan karena dapat memicu konflik sosial, hla ini dikarenakan suami istri ini hampir semua bersal dari kalangan yg berbeda (suku dan budaya), yang kedua yaitu dampak psikologis terhadap anak dalam Rumah Tangga tersebut (jika telah memiliki anak). Yang ketiga hampir $80 \%$ korban dalam kekerasan dalam rumah tangga adalah wanita, kita selalu memprioritaskan untuk melindungi wanita, anak, atau orang yg berada di bawah kekuasaan pelaku dalam lingkup keluarganya (pembantu, anak angkat, anak titipan, maupun siapapun yg tinggal bersama keluarga tersebut).

Undang-undang tentang penanggulangan KDRT telah memadai, sudah mendesai sedemikian rupa. Meskipun masih perlu di update, yang pertama itu belum ada secara terang tertulis bahwa kalau misalnya ada kasus KDRT maka harus didahulukan upaya penyelesaian di luar pengadilan. Karena rata-rata korban mengadu ke polisi hanya untuk memberi pelajaran kepada suaminya. Namun ketika suaminya telah ditahan korban malah datang untuk menangis nangis meminta untuk suaminya di lepaskan. Bahkan sampai berkali kali mengajukan aduan. Oleh karena itu kami mengambil tindakan untuk di SP3 kan, dengan catatan jika suatu saat jika ada laporan lagi maka akan kami lanjutkan sampai ke pengadilan dan tidak dapat kami bantu untuk pencabutan tuntutan lagi.

Maka, dapat disimpulkan Perlindungan secara represif dilaksanakan Polsek Mandai yang bekerjasama dengan Forum Penanganan Korban Kekerasan terhadap Perempuan dan Anak (FPK2PA). Bentuk perlindungan Polsek Mandai meliputi memantau kondisi kesehatan korban dan meminta visum et repertum, memberikan konseling, menempatkan korban di rumah aman (shelter), memberitahukan perkem-bangan penanganan kasus, serta menjamin keselamatan korban yang mencabut aduannya. Perlindungan tersebut sesuai dengan ketentuan Pasal 17 UU Penghapusan KDRT dan Pasal 10 Perkapolri Nomor 3 Tahun 2008. Namun ada hak yang tidak diperoleh korban yaitu mendapatkan surat perintah 
perlindungan dari pengadilan sebagaimana diatur dalam Pa-sal 16 ayat (3) UU Penghapusan KDRT.

2. Hambatan yang dihadapi penyidik kepolisian dalam Penganggulangan Tindak Pidana KDRT di wilayah hukum Polsek Mandai

a. Kendala dalam meminta penetapan perintah perlindungan dari pengadilan

1). Tidak adanya peraturan pelaksana yang mengatur pe-rintah perlindungan Perintah perlindungan sebagai hak korban yang telah diatur dalam Pasal 16ayat (3) UU Penghapusan KDRT selama ini belum pernah dilak-sanakan Unit PPA Polsek Mandai karena alasan belum adanya prosedur teknis terkait permintaan surat pene-tapan perintah perlindungan yang seharusnya diatur dalam peraturan pelaksana seperti Peraturan Kapolri. Dalam hal ini perintahperlindungan masih dianggap sebagai hal baru oleh kepolisian sehingga ketentuan dalam UU Penghapusan KDRT saja dianggap belum cukupmenjadi dasar untuk meminta perintah perlin-dungan.

2). Kurangnya pemahaman polisi terhadap pentingnya perintah perlindungan bagi korban. Faktor lain yang menyebabkan polisi Polsek Mandai belum pernah mengajukan perintah perlindungan kepada pengadilan yakni kurangnya pemahaman polisi terhadap pentingnya perintah perlindungandalam mengantisipasi terulangnya kembali tindak KDRT. Unit PPA sendiri tidak menge-tahui kriteria seperti apa suatu tindak KDRTyang menimpa korban dapat dimintakan perintah perlindu-ngan. Demikianpula dengan prosedur yang seha-rusnya dapat dilaksanakan meskipun tanpa peraturan pelaksana mengingat dalam UU Penghapusan KDRT sudah jelas bahwa korban berhak mendapat perintah perlindungan dari pengadilan yang dimintakan oleh polisi di mana korban tersebut mengadukan kekerasan yang diala-minya.

b. Kendala dalam memantau kondisi kesehatan korban dan meminta visum etrepertum

1). Tidak adanya anggaran untuk membayar visum et repertum Biaya untuk meminta visum menjadi per-soalan sebab tidak ada anggarankhusus untuk membayar biaya visum et repertum. Kendala ini disebutkan oleh Briptu Dian Ratna, salah seorang anggota Unit PPA yang menyatakan bahwa: "tidak adanya dana untuk meminta visum merupakan kendala bagi polisi karena seharusnya biaya memintavisum itu ditanggung oleh berbagai lembaga berjejaring sehingga korban KDRT tidak perlu membayarnya. Namun terdapat beberapa rumah sakityang tidak tergabung dalam lembaga berje-jaring penanganan korban kekerasan sehingga tetap dikenakan biaya untuk permintaan visum etrepertum sehingga pihak Unit PPA lah selaku lembaga yang menangani kasus tersebut yang harus membayar biaya visum."

2). Keluarnya hasil visum et repertum membutuhkan waktu lama. Hasil visum et repertum seharusnya bisa keluar dalam waktu paling lama 20hari, tetapi ada rumah sakit yang menyerahkan hasil visum et repertum kepada penyidik lebih dari 20 hari sehingga memperlambat proses penyidikan di kepolisian. Hal tersebut sebenarnya tidak salah karena bila belum selesai maka batas mak-simal menyerahkan visum et repertum palinglama 40 hari. Namun hasil visum et repertum tersebut sangat penting mengingat hasil visum et repertum dapat dijadikan sebagai bukti pertimbangan untuk melakukan upaya paksa berupa penahanan terhadap pelaku yang sudah berulang kali melakukan kekerasan terhadap perempuan. Padahal dengan adanya hasil visum sebagai salah satu bukti penahanan makahak korban untuk mendapatkan rasa aman telah terpenuhi karena keberadaan korban tidak terancam oleh tersangka atau suaminya sendiri.

c. Kendala dalam melaksanakan pemberian konseling

1). Tidak adanya tenaga psikolog. Tidak adanya tenaga psikolog menjadi kendala sebab banyak kasus KDRTyang dilaporkan ke Polsek Mandai dan korban KDRT yang datang ke Unit PPA untuk melaporkan kasusnya tidak hanya mengalami luka akibat kekerasan fisik, tetapi ada juga yang mengalami ketakutan, tekanan atau trauma yang timbul akibat perlakuan kasar dari pelaku yang melakukan kekerasan secara berulang. Oleh karena itu korban yang melaporkan KDRTdi Polsek Mandai mem-butuhkan pelayanan dari tenaga psikolog yangdapat memberikan penerangan terhadap permasalahan rumah tangganya. Sementara Polsek Mandai sendiri tidak me-miliki petugasyang secara khusus bisa menangani korban yang mengalami tekanan psikis atau petugas yang me-ngerti tentang kondisi psikis korban.

2). Kurang maksimalnya pelayanan konseling untuk korban Adanya sebagian polisi yang kurang berpengalaman dalam menangani dan memperlakukan korban juga menyulitkan Unit PPA untuk melaksanakan perlindungan terhadap korban KDRT, khususnya dalam hal pemberian konseling. Hal ini disebabkan karena beberapa polisi ada yang masih ragu dalam menerima laporan telah terjadi tindak KDRT, kurang memahami persoalan gender dan kurang keterampilan dalam melayani korban (misalnya kurang memperhatikan kondisi psikis korban, kurang tanggap dalam mendengar keluhan korban) sehingga pemberian konseling oleh polisi kurang maksimal.

d. Kendala dalam menempatkan korban di rumah aman (shelter)

1). Keterbatasan sarana dan prasarana. Di Unit PPA seharusnya terdapat ruang istirahat yang fungsinya hamper sama dengan rumah aman yakni berfungsi sebagai tempat istirahat korbansebagai pelapor maupun saksi. Polsek Mandai tidak memiliki ruang istirahat yang dapat digunakan sebagai tempat istirahat bagi korban yang membutuhkan istirahat saat dimintai keterangan sebagai pelapormaupun diperiksa sebagai saksi sekaligus sebagai tempat bagi korban untuk menenangkan diri dan menghindari ancaman pelaku. Hal ini tentu menyulitkan ketika ada korban yang membutuhkan tempat berlindung sementara untuk menjaga keamanan dirinya.

2). Terdapat korban yang enggan ditempatkan di rumah aman. Adanya korban yang enggan dirujuk ke rumah aman justru mempersulit Unit PPA Polsek Mandai untuk melaksanakan dan bertanggung jawab terhadap tugasnya yakni menjaga keamanan dan keselamatan korban selama proses penyelidikan dan penyidikan. Terlebih lagi terhadap korban yang sifatnya tertutup karena takut diancam sangat memerlukan layanan pendampingan psikologis maupun hukum sebagai perlindungan yang tersedia di lembaga-lembaga pena-nganan korban kekerasan.

Dalam hal tidak terlaksananya tugas polisi dalam meminta perintah perlindungan maka Polsek Mandai tetap memberikan perlindungan kepada korban KDRT berda-sarkan ketentuan peraturan Pasal 17 UU Penghapu-san KDRT dan 
Pasal 10 Perkapolri Nomor 3 Tahun 2008 tentang Pembentukan RuangPelayanan Khusus. Beberapa bentuk perlindungan tersebut seperti yang sudah dibahas di atas. Namun bentuk perlindungan tersebut pada kenya-taannya belum efektif untuk mengantisipasi terulangnya tindak KDRT terhadap korban yang sama.

Terpisah dari tidak terlaksananya perintah perlindungan, Unit PPA melakukan beberapa upaya untuk mengatasi kendala dalam perlindungan korban KDRT. Dalam hal ini upaya yang dilakukan bertujuan untuk meminimalkan kendala dalam perlindungan secara represif sesuai ketentuan Pasal 17 UUPenghapusan KDRT dan Pasal 10 Perkapolri Nomor 3 Tahun 2008, meskipun masih ada beberapa kendala yang belum dapat teratasi atau kurang efektifnya upaya dalam mengatasi kendala tersebut. Bebe-rapa upaya yang dilakukan untuk meminimalkan kendala tersebut adalah sebagai berikut:

\section{e. Upaya untuk mengatasi kendala dalam meminta} visum et repertum

1). Menggunakan uang pribadi polisi untuk membayar visum et repertum. Upaya untuk mengatasi kendala tidak adanya dana yang tersedia untukmeminta visum et repertum maka polisi Polsek Mandai berinisiatif menggunakan uang pribadi polisi untuk membayar bia-ya visumet repertum tersebut. Pembiayaan visum et repertum dilakukan oleh polisi yang ditunjuk untuk menangani kasus KDRT tersebut.

2). Menjalin komunikasi dan koordinasi dengan pihak rumah sakit. Upaya untuk mengatasi kendala dalam hal lama keluarnya hasil visum etrepertum maka polisi PPA berupaya sebisa mungkin selalu menjalin komu-nikasi dan koordinasi dengan pihak rumah sakit. Ko-munikasi itudilakukan dalam bentuk menanyakan wa-ktu keluarnya hasil visum etrepertum kepada dokter yang merawat korban. Koordinasi dilakukan dengan cara menemui dokter agar segera mungkin menge-luarkan hasil visum etrepertum dengan menjelaskan alasannya yaitu pentingnya hasil visum etrepertum sebagai salah satu alat bukti untuk memperlancar pro-ses penyidikan.

f. Upaya untuk mengatasi kendala dalam pelaksanaan pemberian konseling

1). Bekerja sama dengan lembaga FPK2PA DIY untuk memberikan konseling. Upaya yang dilakukan polisi Polsek Mandai untuk mengatasi kendala tidak adanya tenaga psikolog yang dapat memberikan pendampi-ngan psikologis/konseling kepada korban KDRT ada-lah melakukan kerja sama dengan lembaga yang tergabung dalam FPK2PA agar bersedia mendatangkan tenaga psikolog ke Unit PPA untuk mendampingi kor-ban.

2). Mengikuti pendidikan pengembangan spesialis Polwan PPA. Dalam rangka untuk meningkatkan pemahaman anggota PPA mengena persoalan gender dan meningkatkan keterampilan terkait cara menangani atau memperlakukan korban maka para anggota Unit PPA diberi kesempatan untuk mengikuti pendidikan dan pelatihan yang diselenggarakan oleh Lembaga Pendidikan Polri (Lemdikpol) yang bertujuan untuk meningkatkan penge-tahuan dan keterampilan polisi PPA dalam menangani anak dan perempuan yang menjadi korban kejahatan. Akan tetapi tidak semua anggota Unit PPA dapat mengikuti pendidikan pengembangan spesialis tersebut karena jumlah peserta yang dapat mengikuti pendidikan pengembangan dibatasi hanya satu orang dari Polresta yang dapat diajukan ke Polda DIY untuk kemudian diseleksi Se provinsi.

\section{g. Upaya untuk mengatasi kendala dalam menempatkan} korban di rumah aman

1). Bekerjasama dengan lembaga FPK2PA DIY yang menyediakan shelter. Upaya yang dilakukan penyidik PPA untuk mengatasi kendala tidak adanya ruang istirahat di Polsek Mandai adalah dengan melakukan kerja sama dan koordinasi dengan lembaga yang tergabung dalam FPK2PA yang menyediakan tempat istirahat atau rumah aman bagi perempuan dan anak korban kekerasan.

2). Memberikan pengertian kepada korban mengenai hakhaknya. Untuk mengatasi kendala korban yang bersifat tertutup dan enggan ditempatkan di rumah aman adalah Polsek Mandai memberitahukan dan memberikan pengertian kepada korban mengenai hak-haknya yang salah satunya adalah korban berhak dirujuk ke rumah aman jika keadaannya terancam dan tidak memungkinkan kembali ke rumahnya. Selain itu Unit PPA juga mengadakan penyuluhan dan sosialisasi untuk menyampaikan kepada masyarakat mengenai keberadaan Unit PPA dan penanganan korban pada Unit PPA agar korban mau terbuka untuk melaporkan kekerasan dan mengerti akan hakhaknya sebagai korban

UU-PKDRT No. 23 tahun 2004, terlepas dari debat yang melingkupinya, telah menggeser wilayah persoalan privat menjadi persoalan publik. Ada harapan besar dari implementasi UU ini diantaranya terhentinya budaya keke-rasan yang ada di tengah masyarakat, dimulai dari wilayah yang paling menetukan yaitu rumah. Stereotype jender yang telah melekat pada laki-laki dan perempuan, seringkali menjebak kedua jenis kelamin ini pada posisi yang sulit. Hal ini juga menandakan, mereka yang bergerak pada wilayah feminist legal theory yang berusaha merekonstruksi sistem hukum yang netral, obyektif, dan transformative, mulai menuai hasil. Netralitas hukum yang mengandaikan imparsial (tidak memihak) pada satu pihak atau golongan, sehingga dalam perkembangannya hukum berdampak pada keberadaan perempuan. Obyektivitas hukum dicapai jika polaritas dan dikotomi maskulin-feminin dihilangkan. Dengan demikian, kekerasan di wilayah domestik juga dianggap sebagai tindak kejahatan. Transformatif bermakna tidak hanya perubahan dalam traktat hukum, melainkan modifikasi mekanisme hukum yang adil bagi perempuan. Feminist legal theory memperjuangkan konsep hukum yang didasari oleh pe-ngalaman perempuan sebagai starting point. Kesadaran hukum bagi perempuan pun perlu dibangun untuk mempe-roleh hak-hak dan kesempatan yang sama (Steffen, 1993; Rita, 2000).

Jika ketidaksetaraan dan ketidakadilan dalam menempatkan posisi laki-laki dan perempuan adalah konstruksi masyarakat, maka kekerasanpun adalah bagian dari konstruksi itu. Masyarakat bertanggung jawab atas pembela-jaran tentang bagaimana menjadi laki-laki, sehingga laki-laki mengaktualisasi kemaskulinannya melalui tampilan diri yang macho, gagah, kuat, agresif (Sanford, 1983). Maka sekarang saatnya bagi masyarakat mengubah pela-belan jender ini menjadi lebih manusiawi, sehingga cara-cara mengaktualisasikan diri menjadi lebih assertif di masyarakat. Dengan demikian, keadilan jender sebagai suatu kondisi dan perlakuan yang adil terhadap perempuan dan laki-laki dapat 
terwujud. Diperlukan langkah-langkah untuk menghentikan hal-hal yang secara psikis, politik, dan sosial budaya menghambat perempuan dan laki-laki untuk bisa berperan dan menikmati hasil dari perannya itu. Kese-taraan yang adil merupakan suatu konsep yang mengakui faktor-faktor khusus seseorang serta memberikan haknya sesuai dengan kondisi orang tersebut (person-regarding equality). Jadi, bukan memberikan perlakuan yang sama kepada individu yang berbeda kebutuhan dan aspirasinya, tapi memberikan perhatian yang sama kepada setiap indi-vidu agar kebutuhannya dapat terpenuhi.

Sudah waktunya pemerintah bersama-sama masya-rakat mencanangkan Zero tolerance terhadap kekerasan. Artinya tidak ada toleransi sekecil apapun terhadap tinda-kan kekerasan terhadap perempuan, baik dalam keluarga, masyarakat, dan negara. Kebijakan ini sebagai bagian dari penghapusan segala bentuk diskriminasi terhadap perem-puan (Vony, 2002).

Hal ini sejalan dengan PBB (united Nations) yang telah membentuk Komisi Kedudukan Perempuan (Commission on the Status of Women) yang bertugas menentukan lang-kahlangkah, kebijakan, serta memantau tindakan PBB bagi kepentingan perempuan. Hal ini dilakukan karena PBB melihat bahwa diskriminasi terhadap perempuan tetap berlangsung di banyak negara sehingga perlu dikeluarkannya sebuah Deklarasi Penghapusan Diskriminasi Terhadap Perempuan

\section{KESIMPULAN}

Berdasarkan hasil penelitian dapat disimpulkan bahwa, Perlindungan secara preventif dilakukan melalui kegiatan penyuluhan dan sosialisasi perlindungan perem-puan dan anak Unit PPA bekerjasama denganFPK2PA. Kegiatan tersebut sesuai dengan ketentuan Pasal 12 ayat (1) hurufa UU PKDRT yaitu "pemerintah menyeleng-garakan komunikasi, informasi,dan edukasi tentang keke-rasan dalam rumah tangga; dan Perlindungan secara represif dilaksanakan Polsek Mandai yang bekerjasama dengan Forum Penanganan Korban Kekerasan terhadap Perempuan dan Anak (FPK2PA). Bentuk perlindungan Polsek Mandai meliputi memantau kondisi kesehatan korban dan meminta visum et repertum, memberikan konseling, menempatkan korban dirumah aman (shelter), memberitahukan perkembangan penanganan kasus, serta menjamin keselamatan korban yang mencabut aduannya. Perlindungan tersebut sesuai dengan ketentuan Pasal 17 UU Penghapusan KDRT dan Pasal 10 Perkapolri Nomor 3 Tahun 2008. Namun ada hak yang tidak diperoleh korban yaitu mendapatkan surat perintah perlindungan dari pengadilan sebagaimana diatur dalam Pasal 16 ayat (3) UU PenghapusanKDRT; serta Kendala yang dihadapi Polsek Mandai dalam perlindungan perempuan korban kekerasan dalam rumah tangga diantaranya adalah pertama, tidak adanya peraturan pelaksana terkait perintah perlindu-ngan. Kedua, keterbatasan dana dan keluarnya hasil visum et repertum membutuhkan waktu yang lama. Ketiga, keterbatasan sumber daya manusia seperti tidak adanya tenaga psikolog, kurang maksimalnya pelayanan konseling untuk korban, dan kurangnya pemahaman polisi terhadap pentingnya perintah perlindungan bagikorban. Keempat, keterbatasan sarana prasarana dan terdapat korban yang enggan ditempatkan di rumah aman. Pengawasan Komisi Penyiaran Indonesia Daerah Sulawesi Selatan terhadap program Pemilihan Kepala Daerah tahun 2018 telah dilaksanakan, namun belum berjalan sebagaimana mestinya.

\section{DAFTAR PUSTAKA}

Barda Nawawi Arif. (2007). Masalah Penegakan Hukum dan Kebijakan Hukum Pidana Dalam Penanggulangan Kejahatan, Penerbit Kencana.

Didik M. Arif Mansur \& Elisatris Gultom. (2007). Urgensi Perlindungan Korban Kejahatan, Antara Norma dan Realita, PT. Raja Grafindo Persada.

Fathul Djanah. (2006). Kekerasan Terhadap Istri, LKIS, Yogjakarta.

Masruchin Rubah. (2001). Asas-Asas Hukum Pidana, UM Press Malang.

M. Khoidin \& Sadjijono (2007). Mengenal Figur Polisi Kita, Laksbang, Yogyakarta.

Parsudi Suparlan. (2004). Bunga Rampai Ilmu Kepolisian Indonesia, YayasanPengembangan Kajian Ilmu Kepolisian, Jakarta.

[PKKNRI] (2007). Peraturan Kepala Kepolisian Negara Republik Indonesia. No Pol : 10 Tahun 2007 Tentang Organisasi dan Tata Kerja Unit Pelayanan Perempuan dan Anak (Unit PPA) di lingkungan Kepolisian Negara Republik Indonesia.

Ratna Saptari. (2016). Perempuan: Kerja dan Perubahan Sosial, Kalyanamitra, Jakarta.

Rika Saraswati. (2015). Rumah tangga, Perempuan dan Penyelesaian Kekerasan, PT. Citra Aditya Bakti, Bandung, 2015.

Rita Serena Kolibonso. (2000). Kejahatan Itu Bernama Kekerasan Dalam Rumah Tangga.Mitra Perempuan, Jakarta.

Sanford Kadish. (1983). Encyclopedia of Criminal Justice. The Free Press, Collier Macmillan, 1983.

Steffen H. Gifis. (1993). Dictionary Of Legal Term : A Siplified Guide To the Language Of Law, Barrons Educational Seies, New York.

Sulistyowati Irianto \& L. I. Nurtjahyo. (2006). Perempuan di Persidangan, Pemantauan Peradilan Berspektif Perempuan, Yayasan Obor Indonesia, Jakarta.

Tubagus Nitiskara (2001). Ketika Kejahatan Berdaulat Sebuah Pendekatan Kriminologi : Hukum dan Sosiologi, Peradabaan, Jakarta.

Vony Reynata. (2002). Kekerasan Dalam Rumah Tangga, Peradabaan, Bandung. 